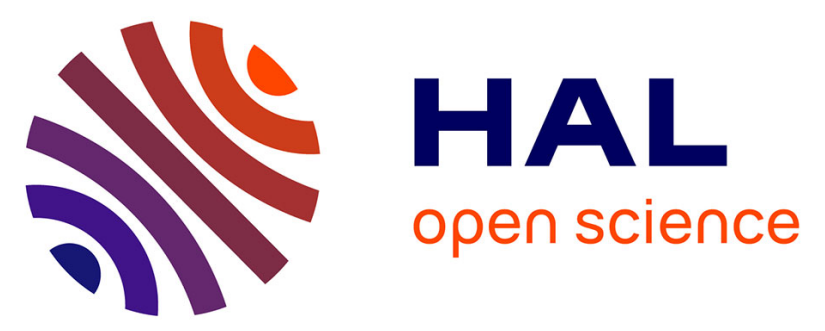

\title{
Establishment and functioning of the savanna marshes of the Lopé National Park in Gabon since the termination of the African humid period and the arrival of humans 2500 years ago
}

Laurent Bremond, Richard Oslisly, David Sebag, Ilham Bentaleb, Charly Favier, Karl Henga-Botsikabobe, Makaya Mvoubou, Alfred Ngomanda, Geoffroy de Saulieu

\section{- To cite this version:}

Laurent Bremond, Richard Oslisly, David Sebag, Ilham Bentaleb, Charly Favier, et al.. Establishment and functioning of the savanna marshes of the Lopé National Park in Gabon since the termination of the African humid period and the arrival of humans 2500 years ago. The Holocene, 2021, 31 (7), pp.1186-1196. 10.1177/09596836211003230 . hal-03197824

\section{HAL Id: hal-03197824 \\ https://hal.science/hal-03197824}

Submitted on 16 Apr 2021

HAL is a multi-disciplinary open access archive for the deposit and dissemination of scientific research documents, whether they are published or not. The documents may come from teaching and research institutions in France or abroad, or from public or private research centers.
L'archive ouverte pluridisciplinaire HAL, est destinée au dépôt et à la diffusion de documents scientifiques de niveau recherche, publiés ou non, émanant des établissements d'enseignement et de recherche français ou étrangers, des laboratoires publics ou privés. 
Laurent Bremond, Richard Oslisly, David Sebag, Ilham Bentaleb, Charly Favier, Karl HengaBotsikabobe, Makaya Mvoubou, Alfred Ngomanda, Geoffroy de Saulieu, Ecotrop Team? Establishment and functioning of the savanna marshes of the Lopé National Park in Gabon since the termination of the African humid period and the arrival of humans 2500 years agoThe Holocene $($ ) The Author(s) 2021 DOI : 10.1177/09596836211003230

\title{
Establishment and functioning of the savanna marshes of the Lopé National Park in Gabon since the termination of the African Humid Period and the arrival of Human 2500 years ago
}

\author{
Laurent Bremond ${ }^{1}$, Richard Oslisly ${ }^{2,6}$, David Sebag ${ }^{3,4}$, Ilham Bentaleb ${ }^{1}$, Charly Favier1, Karl Henga- \\ Botsikabobe ${ }^{4}$, Makaya Mvoubou ${ }^{5}$, Alfred Ngomanda ${ }^{4}$, Geoffroy de Saulieu ${ }^{6}$ and the Ecotrop Team
}

1. Institut des Sciences de l'Evolution de Montpellier (ISEM), EPHE, PSL Research University, Université de Montpellier, CNRS, IRD, Place Eugène Bataillon, CC 065, 34095 Montpellier, France.

2. Cellule Scientifique, Agence Nationale des Parcs Nationaux, BP 20379 Libreville, Gabon.

3. Normandie University, UNIROUEN, UNICAEN, CNRS, M2C, 76000 Rouen, France

4. IRET, BP13354 Libreville, Gabon.

5. Université des Sciences et Techniques de Masuku. Département de géologie. BP 901, Franceville Gabon

6. Patrimoines Locaux et Gouvernance UMR 208, IRD, MNHN, 75005 Paris, France

\# Current address: IFPEN, Geosciences Dept, Rueil-Malmaison, France

Keywords: Gabon, tropical marshes, sediments, multi-proxy analysis, XRF, $\mathrm{d}^{13} \mathrm{C}$, paleoenvironment

\begin{abstract}
Holocene palaeoecological studies in tropical Africa are rare because most lakes either dried out at the termination of the African Humid Period or have since filled up. However, tropical sedge marshes can be an alternative to perform long-term ecological studies. The Lopé National Park (LNP) in Gabon is a mosaic of forest and savanna enclosed in the equatorial forest, where open areas facilitated the development of peat marshes accumulating several-meter-thick sediment. In order to reconstruct the historical dynamic in these marshes through a local and regional point of view, we compared sedimentological, continuous X-ray fluorescence, and stable isotopic analyses on sediment cores from six herbaceous marshes in the LNP. A reliable chronological frame was based on $5014 \mathrm{C}$ dates, over the last 2500 years in most sites, and reaching 9,000 years in one marsh. We show that the origin of these marshes is a major hydrological change, 3450 and 2300 years ago, that affected the entire region, almost concomitantly with the diffusion of Iron Age population. The sedimentation within marshes is homogenous with low intra-site variability. In contrast, high inter-sites variability evidences that the functioning of the marsh itself exerts a much more significant influence than in lakes. However, a regional event is recorded between 1400 and 800 years ago, concurrently with an archaeological trace hiatus throughout the forest hinterland of West Central Africa.Introduction
\end{abstract}

\section{Introduction}

Holocene paleoecological studies from lake and marsh sediments in lowland West and Central Africa are rare because environmental conditions, such as geomorphology and climate, are not conducive for stratigraphic sediment deposit and bioproxy preservation. Dry conditions, North and South of the tropics, have prevented anoxic sediment deposits since the termination of the African Humid Period (Lézine et al., 2011). Between the tropics, late Holocene paleoecological records are more abundant (Jacobson and Bradshaw, 1981), but they remain scarce compared to temperate humid regions such as North America. In these regions the climate favors organic matter accumulation. The peatlands and 
kettle lakes, that are natural geomorphological shallow hollows, offer a multitude of potential sites (Gajewski, 2008). Moreover, in Sudanian and Sahelian savannas, the millennial variability in annual rainfall and dry season length has strongly impacted the groundwater stocks that supply the depressions. The potential deposit areas are subsequently often dried out, resulting in incomplete sedimentary archives. Under wetter climates, as in the Congo Basin, high forest and wetland primary productivity causes a rapid filling up of the depressions and successions from a lake to a flooded forest, to a terra firme or a peat forest and results in a loss of lake sediments. This phenomenon is particularly well visible near M'Baïki in Central African Republic, where many lakes in the forest are at different successional stages of lake replacement by forest, easily recognizable from satellite images (Boulvert and Salomon, 1988). Together, the scarcity of sites suitable for sediment accumulation and climatic conditions unfavorable to sediment preservation result in scattered paleodata at the regional scale. This low spatial density raises the question of the validity of broad-scale spatiotemporal reconstruction changes (Hély and Lézine, 2013) and, more generally, of the spatial and temporal scales of representativeness of the different bioproxies used in tropical areas. Thus, the long term ecology of the lowland West and Central Africa is poorly known. Several questions are controversial, in particular the central one on the role of Human and climate on vegetation at the termination of the African Humid Period (Bayon et al., 2019; Garcin et al., 2018; Maley et al., 2018; Phelps et al., 2020; Shanahan et al., 2015). Much of the discord can be probably explained by the fact that there is too little data available and that local events are extrapolated to an entire continental region.

The Lopé National Park (LNP) is a mosaic of forest and savanna enclosed in the African equatorial moist forest (White and Abernethy, 1997) where open areas facilitated the development of peat marsh systems allowing reconstructions of the Holocene vegetation and environmental history (Ngomanda et al., 2005). Exceptionally in a tropical ecosystem, this site is a field laboratory where spatiotemporal multiproxy approaches can be explored and discussed in light of the numerous archaeological works also available for the study area (Oslisly and White, 2000). It offers the possibility to compare inter-site signals to investigate the spatial resolution of each studied proxy (Jackson, 1990) within a restricted area of less than $50 \mathrm{~km}^{2}$, and the intra-site signals to study the replicability and variability of the records (Barber et al., 1998). Here, we investigate the spatial scale of records by tropical sedge's marshes and address the timing, the origins of the start of the sedimentation, and the historical dynamic in these marshes through a local and regional point of view. For this purpose, six herbaceous marshes were cored; diachronic and synchronic sedimentological and geochemical analyses were performed based on $50{ }^{14} \mathrm{C}$ dates ensuring reliable chronological frames.

\section{Material and Method}

\section{Study area}

The LNP is located in central Gabon. Most of the park is covered by a semi-evergreen lowland rainforest and forest-savanna mosaics corresponding to the Congolian Mosaic of lowland rain forest and secondary grassland (White, 1983). The consensus about the origins of these savannas is that they are natural, relicts of a drier period (Descoing, 1974), and have persisted for thousands of years (Oslisly, 2001). Today, these savannas are maintained open by recurrent fires lit by humans (White, 1992). Since 1993, the LNP fire management program comprises the annual burning of most of the open landscapes (Jeffery et al., 2014).

The LNP area receives about $1500 \mathrm{~mm}$ annual rainfall, an amount substantially lower than its surroundings, with a long dry season lasting about three months from mid-June to mid-September and a short dry season in January-February (Peyrot et al., 2003).

Jeffery (2014) and White and Abernethy (1997) differentiated two types of savannas. The first type, mostly found in the north of the LNP, is dominated by the grass Anadelphia afzeliana. The second type, typical of the southern part, is dominated by grasses Hyparrhenia diplandra, Ctenium newtonii, Andropogon pseudapricus, Schizachyrium platyphyllum and Panicum nervatum. The shrubs are the same in both types: Sarcocephalus latifolius, Crossopteryx febrifuga and less frequently Psidium guineense and Bridelia ferruginea 


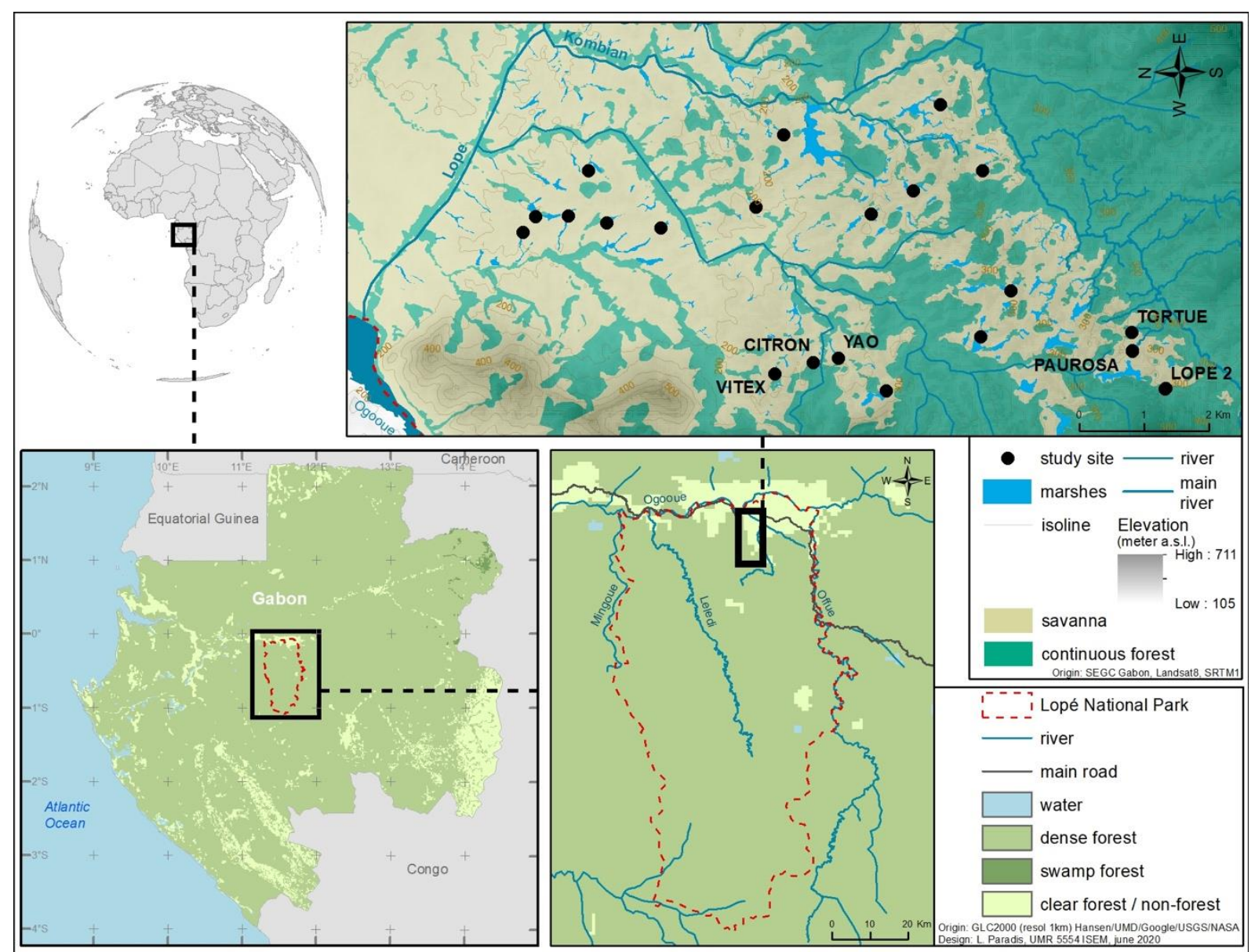

Figure 1. Study area and location of the 23 visited marshes. The 6 marshes with studied fossil material are labelled

(White and Abernethy, 1997). At present, the savanna tree cover appears related to the fire return period (Jeffery et al., 2014). Annual fires significantly reduce the tree cover compared with 2- to 3-year fire return. Both fire frequencies prevent forest colonization over the savanna, contrary to areas protected from fire (Jeffery et al., 2014).

Several types of forests were described by White and Abernethy (1997) according to their structure and species composition: forest groves in savannas, gallery forest, Marantaceae forest, and mature forest. The gallery forests link the savannas with the forest block along the depressions and small rivers (Figure 1 and see photographs in SI 1 and in Henga- Botsikabobe et al. (2020), and Sebag et al. (2016)).

The herbaceous marshes investigated in this study are many in the low-lying areas, usually fringed by the gallery forests. They are dominated by sedges: Rhynchospora corymbosa, Kyllinga cf. echinata (Cyperus afroechinatus), Scleria verrucosa in their wettest parts and Ascolepis capensis in their driest parts. The transition between the marshes and the surrounding savanna is often visible by the presence of tall grasses, mainly Coelorachis afraurita, Euclasta condylotricha. When marshes dry out during the long dry season, these grasses can invade the marshes themselves (Figure 2).

\section{Coring design}

Not every marsh in the LNP has accumulated sediments. 23 sites were visited and the sediment depth measured with an iron rod (Table Marsh Surface Samples in SI "Data\#BREMOND2021); names of marshes are in italic in the text). The positions and altitudes of each site were measured with a GPS to compare their topographic positions to the location of the two major rivers of the study area, the Lopé and Kombian rivers (Figure 2. and see Figure SI 1 Photographs). Both flow into the Ogooué river on the 


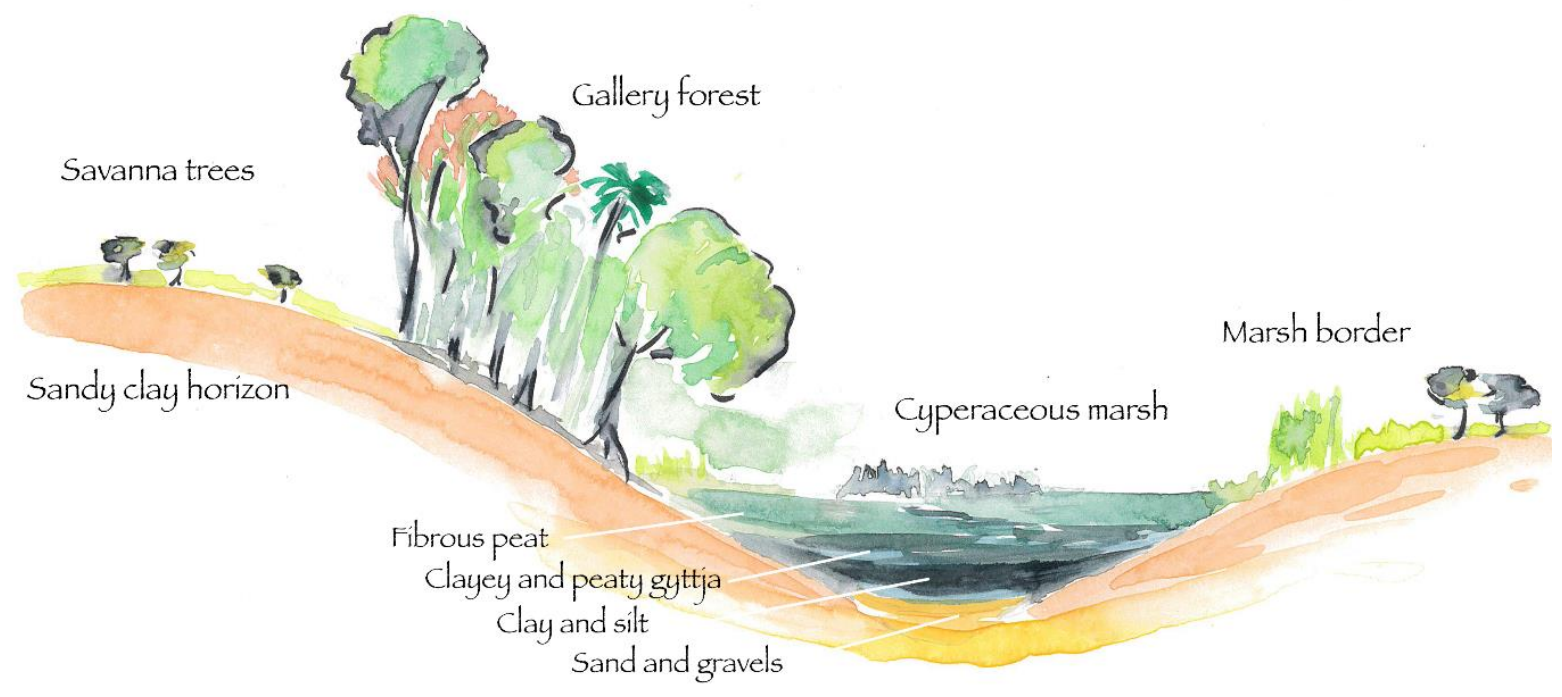

Figure 2. Illustration of a marsh in longitudinal section.

Northern part of the Park. A simple linear regression model of the marshes and rivers altitudes respective to their geographical location was performed using the R package "scatterplot3d" (Ligges and Mächler, 2002).

Six marshes were selected in the savanna domain of the Lopé National Park because they had more deposits than the majority. (Figure 1; Table "Marsh Surface Samples" in SI "Data\#BREMOND2021). Each of them was cored twice. The first coring campaign took place in March 2012, 2013, and 2014, using a 8-cm-diameter Russian corer (1-m-long chamber). 1-meter sections were taken in two adjacent parallel holes (less than $20 \mathrm{~cm}$ apart), with 20 to $30 \mathrm{~cm}$ overlaps among sections. In Paurosa marsh, the overlap was not conserved because of technical problems. Each section was cut into 1-cm samples, stored in plastic bags. The second coring campaign took place in March 2015, using a 5-cm-diameter Russian corer, with 1-m sections extracted from a single hole. The sections were wrapped in plastic and placed in PVC tubes for transport to be later analyzed in continuous by X-ray fluorescence (XRF) measurements.

Performing two overlapping parallel cores permitted avoiding any contamination between the segments, as the tip of the Russian corer does not disturb the top of the sediment to be taken subsequently, but a short offset can occur at the transitions. Using a single hole was interesting to save time and transport weight.

All the cores reached a basal sand layer, not sampled as the corer tip did not pass through this layer. On the Lopé2 marsh only, the corer was able to go through a sandy clay layer and clay-silt sediment was collected below it.

\section{Radiocarbon dating}

50 radiocarbon datings were obtained on sediment cores retrieved by the first campaign, mainly from Cyperaceae seeds, pieces of Elaeis guineensis seeds, or leaf fragments (6 to 11 for each core; see SI Table 1). Seeds and leaves are annual products of a living plant and likely deposited rapidly in the marsh, ensuring that their age is coeval to sediment deposition. We preferred this to dating charcoals or bulk sediment. Charcoal is produced by incomplete combustion of a living or dead tree/shrub, possibly very 
old. This effect is called 'inbuilt age' or 'old wood effect' (Gavin, 2001). The accuracy of bulk organicrich sediment dating from swamps has been heavily debated (Holmquist et al., 2016; Nilsson et al., 2001). Bulk sediment carbon is the result of a mixture of carbon with different history and ages, with root-derived organic matter typically younger than the time of bulk deposition and clastic sediment carbon typically older. Depending on the sites studied, this resulted in an overall juvenification, aging, significant or not of radiocarbon dates from bulk sediment in swamps. In order to avoid this effect, we chose seeds or plant macroremains, when possible, to avoid bulk sediment dating. Only in the bottom of some marshes, where no seeds could be found, and a few dates were obtained from bulk sediments. In these parts, the sediment is very poor in organic matter and probably not disturbed by roots.

Leaf fragments and seeds were collected by sieving (150um) 5-10g of sediment selected at regular depth intervals (see Figure SI 1. Photographs). When no seed was found, the upper or lower level was sampled. If too little material was recovered for AMS dating, plant remains from 2-3 cm adjacent layers were mixed.

The ${ }^{14} \mathrm{C}$ analyses were performed at Poznan Radiocarbon Laboratory (Poland) following the protocol described by Goslar et al. (2004) and at the Laboratoire de Mesure ${ }^{14} \mathrm{C}$ (LMC14) on the ARTEMIS accelerator mass spectrometer in the CEA Institute at Saclay (Atomic Energy Commission), following the protocol described by Dumoulin et al. (2017). The age-depth models were computed with the Bacon software (Blaauw and Christen, 2011), using INTCAL13 and NH3 zone post-bomb calibration curves (Reimer et al., 2013).

\section{Geochemical and sedimentological analyses}

The lithology of the core was described and photographed in the field after sampling (Figure SI 2. Photographs and logs of the core segments). The classification was detailed according to Chawchai et al. (2016) by using the texture and the amount of the organic content with the following classification: gyttja clay/silt $=3-6 \%$ Organic Matter content $(\mathrm{OMc})$; clayey gyttja $=6-30 \%$ OMc; gyttja $=>30 \%$ OMc; peaty gyttja $>40-60 \%$ OMc; peat $>60 \%$ OMc. The presence of vegetal fibers with little degradation in very large quantities is also reported as well as layers containing sand.

All geochemical and sedimentological analyses were performed on the cores collected during the first campaign except for the continuous X-ray fluorescence analysis.

Organic Matter content was measured by Loss On Ignition (LOI) performed on $1 \mathrm{~cm}^{3}$ of sediment, following the procedure described by Heiri et al. (2001). LOI was obtained for Lopé2, Citron, and Yao cores, each $11-13 \mathrm{~cm}$ depth intervals.

$X$-ray fluorescence analyses were performed every $1 \mathrm{~cm}$ for several primary elements on bulk sediment with an Innov-X XRF portable analyzer (pXRF) in "soil" and "Min+" mods. Measurements can be slightly affected by pore water and mean porosity (Weltje and Tjallingii, 2008). Measurement reproducibility and comparison with conventional XRF are satisfying (Caporale et al., 2018).

Continuous $\mathrm{X}$-ray fluorescence (XRF) analyses were performed on cores collected during the second campaign with an Avaatech core scanner (X-Ray beam generated with a rhodium anode) at EDYTEM Laboratory (CNRS-University Savoie Mont Blanc, France). One run of analyses was performed with a 5 - $\mathrm{mm}$ resolution with a voltage of $10 \mathrm{kV}$, an intensity of $1.2 \mathrm{~mA}$ and a counting time of $15 \mathrm{~s}$ were applied; for the second run, a voltage of $30 \mathrm{kV}$, an intensity of $0.75 \mathrm{~mA}$ and a counting time of $30 \mathrm{~s}$ were applied. To compare intra-site sediments we used the five elements, $\mathrm{Si}, \mathrm{K}, \mathrm{Ca}, \mathrm{Ti}$, and Fe measured with pXRF and XRF on the two sequences of each marsh. We aligned them using MATCH program (Lisiecki and Lisiecki, 2002) to provide a composite sediment depth (cd), ranging from the top of the sediment to the bottom (Figure SI 3. XRF alignment).

To compare XRF measures between cores (i.e. inter-sites) we applied PCA analysis (Principal Component Analysis) to some elemental data (Avaatech) to reduce the dimensionality and identify elements with similar behavior and controlled by the same process (Chawchai et al., 2016). Among the 13 elements recorded along almost all the cores, only $\mathrm{Al}, \mathrm{Si}, \mathrm{S}, \mathrm{K}, \mathrm{Ca}, \mathrm{Ti}$, and $\mathrm{Fe}$ were used for PCA analysis because $\mathrm{P}, \mathrm{Cl}, \mathrm{Cr}$, and $\mathrm{Mn}$ are not well recorded with these voltages and intensities in organic- 
rich sediment or peat (Figure SI 4. PCA on XRF data of the 6 cores) and Rh is an element associated with the source of the spectrometer (rhodium anode).

\section{Stable isotopic analyses}

227 samples from the six marsh cores were analyzed for bulk carbon and nitrogen contents (\%) and isotopic ratios $\left(\delta^{13} \mathrm{C}\right.$ and $\left.\delta^{15} \mathrm{~N}\right)$. Bulk marsh sediment isotopic composition represents a mixture of that of plants that grow in (leaf and roots) and around the marsh. Isotopic analyses were additionally performed on some leaf samples from main plants growing in and around the marshes and on 23 surface marsh samples, each composed to the mixture of 15 small samples taken over the surface of the marsh. Sample preparations for sediment and plants follow the same procedure described in Nguetsop et al. (2013). Briefly, it consists of grinding previously overnight dried $\left(50^{\circ} \mathrm{C}\right)$ samples and sieving through a $125 \mu \mathrm{m}$ mesh. The well homogenized $<125 \mu \mathrm{m}$ powder fractions are weighed $(<1 \mathrm{mg}$ for plants to about $10 \mathrm{mg}$ for sediments) into tin capsules. $\mathrm{C}$ and $\mathrm{N}$ isotopic and elemental analyses on core sediment samples were done in 2016 by the UC-DAVIS IRMS facilities (University of California). The 202 sediment samples were not acid wash treated with $\mathrm{HCl}$ to remove carbonates but 15 samples were duplicated with acid treatment without any change being observed in the carbon isotopic composition ratios of the bulk sediments. Those on leaves and surface sediment samples were done in 2017 by LEHNA laboratory IRMS facilities (University of Lyon). Results are expressed as $\delta^{13} \mathrm{C}$ and $\delta^{15} \mathrm{~N}$ using the conventional delta $(\delta)$ notation relative to the Vienna Pee Dee Belemnite (V-PDB) for C isotopic ratios and to the atmospheric nitrogen $(\mathrm{V}-\mathrm{N} 2 / \mathrm{Air})$ for $\mathrm{N}$ isotopic ratios: $\delta(\%)=[($ Rsample/Rstandard $)$ - 1] $x 1000$, where Rsample and Rstandard are ${ }^{13} \mathrm{C} /{ }^{12} \mathrm{C}$ and ${ }^{15} \mathrm{~N} /{ }^{14} \mathrm{~N}$ ratios of the sample and standard, respectively. Analytical precision for $\delta^{13} \mathrm{C}$ and $\delta^{15} \mathrm{~N}$ was better than 0.1 and $0.2 \%$ respectively at UCDAVIS and better than $0.1 \%$ for both $\delta^{13} \mathrm{C}$ and $\delta^{15} \mathrm{~N}$ at LEHNA. Results of elemental $\mathrm{C}$ and $\mathrm{N}$ contents are expressed as (\%) and are also presented as $\mathrm{C} / \mathrm{N}$ ratios. We also added the carbon isotopic composition of fresh plants taken from a previous study conducted in La Lopé Réserve (Hatté, 2000) and one from Daryl Codron (Sarcocephalus latifolius, unpublished data) (Table "D13C Fresh Plants" in SI “Data\#BREMOND2021).

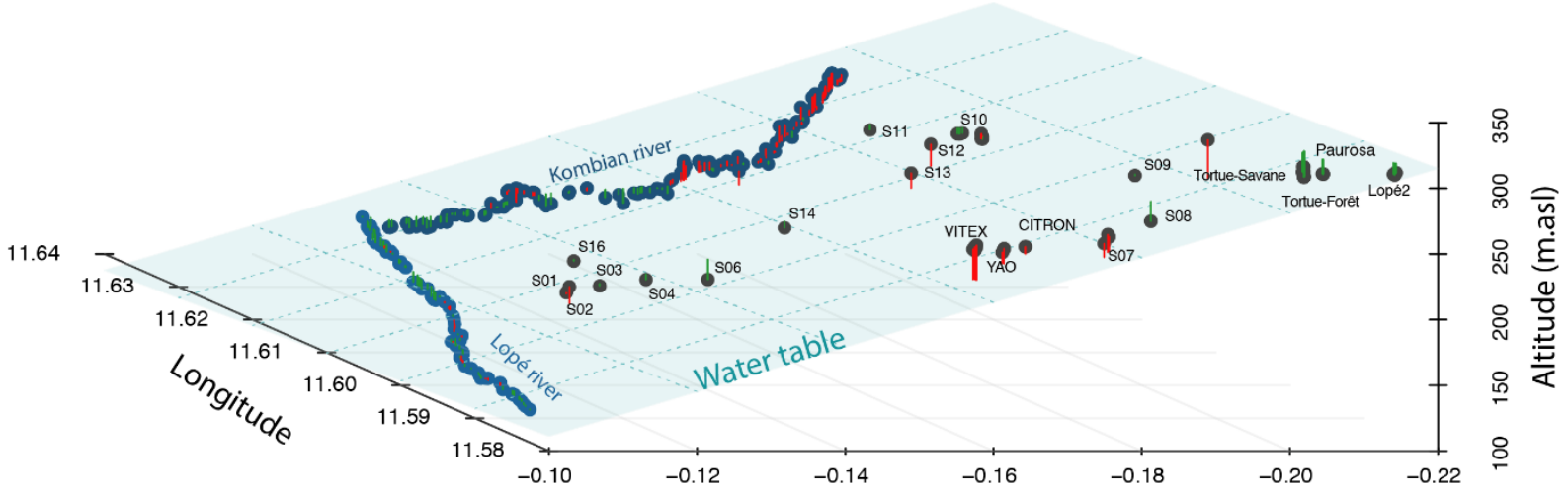

Latitude

Figure 3. Distribution of the elevation of the 23 visited marshes and the two rivers of the studied zone, according to their geographical location (longitude/latitude) and their elevation. The plane represents the linear regression model between these 3D points. Red and green bars respectively indicate positive and negative differences between true elevation and regression plane. 


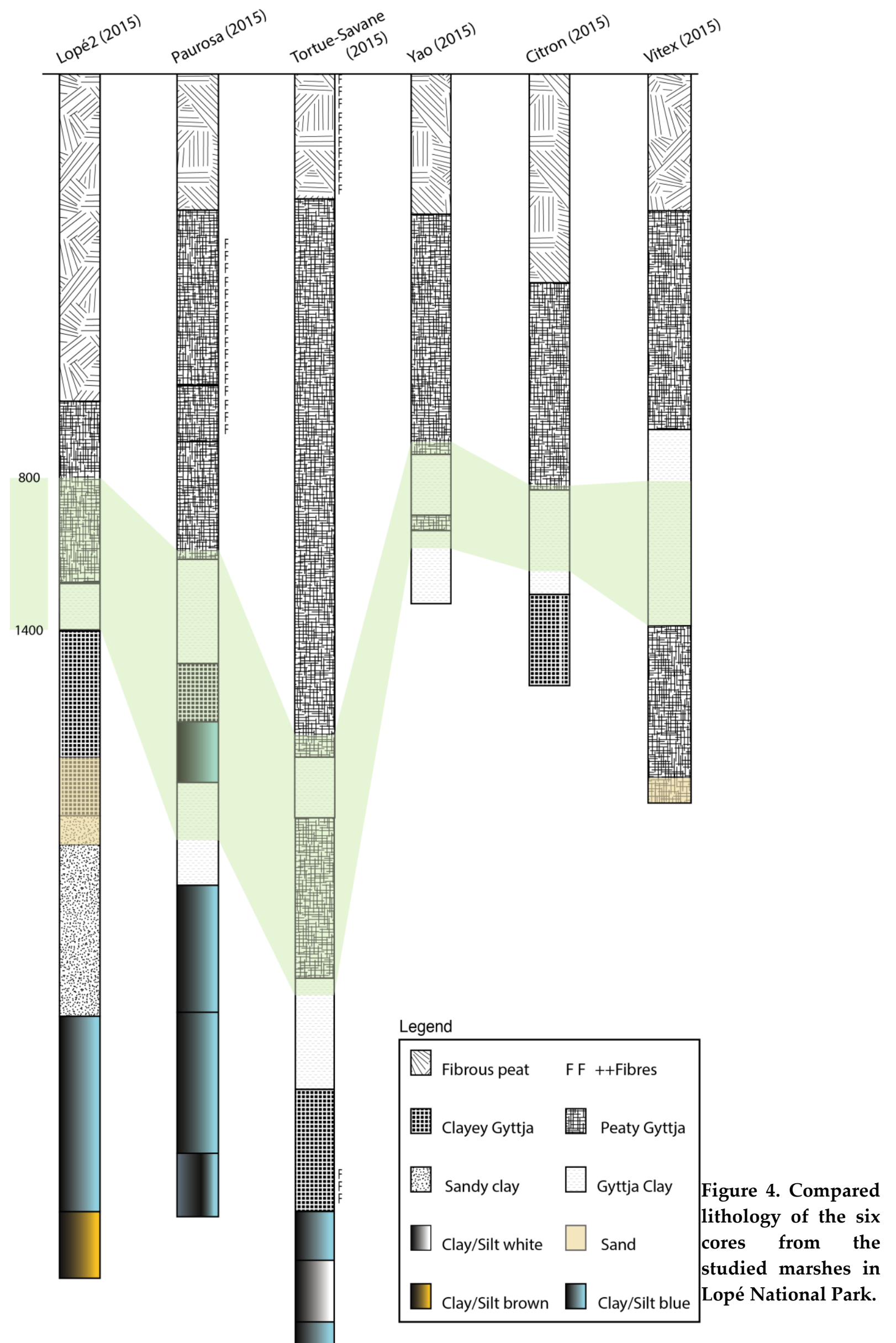




\section{Results}

\section{Topography of the La Lopé Marshes}

Figure 3 displays the geographical locations (longitude/latitude) and elevations of the 23 marshes visited and those of the Kombian and Lopé rivers. The regression plane indicates that the marshes are consistently distributed on the same plane oriented South-Southwest, with $200 \mathrm{~m}$ altitudinal gradient. Some marshes are few meters below $(\max -20 m)$ or above $(\max +30 m)$ the plane.

\section{Lithostratigraphy}

The six cores broadly share a common distribution of lithological facies (Figure 4 and Figure SI 2. Photographs and logs of the core segments). In the longest sequences (Tortue-Savane, Paurosa, and Lopé2), the basal units consist in $20-\mathrm{cm}$ to $80-\mathrm{cm}$ thick blue/white clay and silt, with a red-brownish clay in deepest layers of Lopé2, the oldest sequence. A sandy clay unit supersede this layer in Lopé2 while a similar unit is inserted in the upper part of the blue clay and silt unit in Paurosa.

Sand mixed with Gyttja is retrieved at the base of Vitex and in Lopé2 just on top of the sandy clay layer. Above that a second unit of clayey sediment (Gyttya Clay) is found in all the cores. A third unit, made of clayey and more or less fibrous peaty gyttja (Clayey gyttja), to a few tens of centimeters to more than one meter thick, is presents in all the cores. Finally, all core tops are composed of fibrous peat made of recent cyperaceous debris from $40 \mathrm{~cm}$ thick in Tortue-Savane to $110 \mathrm{~cm}$ in Lopé2.

Age depth models

Over the 50 dates on the six marshes selected for coring, only 3 inversions occurred (SI Table 1). Figure 5 summarizes the age-depth models of the six marshes (see also Figure SI 6. to see the details of each age-depth models). All ${ }^{14} \mathrm{C}$ dates performed in the top fibrous peat unit are post-1950 (post-bomb nuclear testing). Paurosa and Tortue-Savane present higher sedimentation rates than the others (c. 5 yr./cm versus c. $12 \mathrm{yr} . / \mathrm{cm}$ ). The sedimentation within each marsh starts between 1950 and 2400 years ago, except for Lopé2 where the corer went through a layer of sandy clay dated between 3450 and 2300 cal yr BP (calibrated rounded median value; Identical afterwards. Refer to SI Table 1 for the uncalibrated age and associated probability range). A seed of Elaeis sp. found in this sandy layer was dated at 1810 ${ }^{14} \mathrm{C} \mathrm{BP}$ but this age is much younger than expected from the other dates. The bottom of Lopé 2 is dated at $9000 \mathrm{cal} \mathrm{yr} \mathrm{BP}$, by using a date at $8610{ }^{14} \mathrm{C}$ cal yr BP around $365 \mathrm{~cm}$ (depth re-estimated visually from a previous core; see core photography in SI.2- Photographs of the core segments).

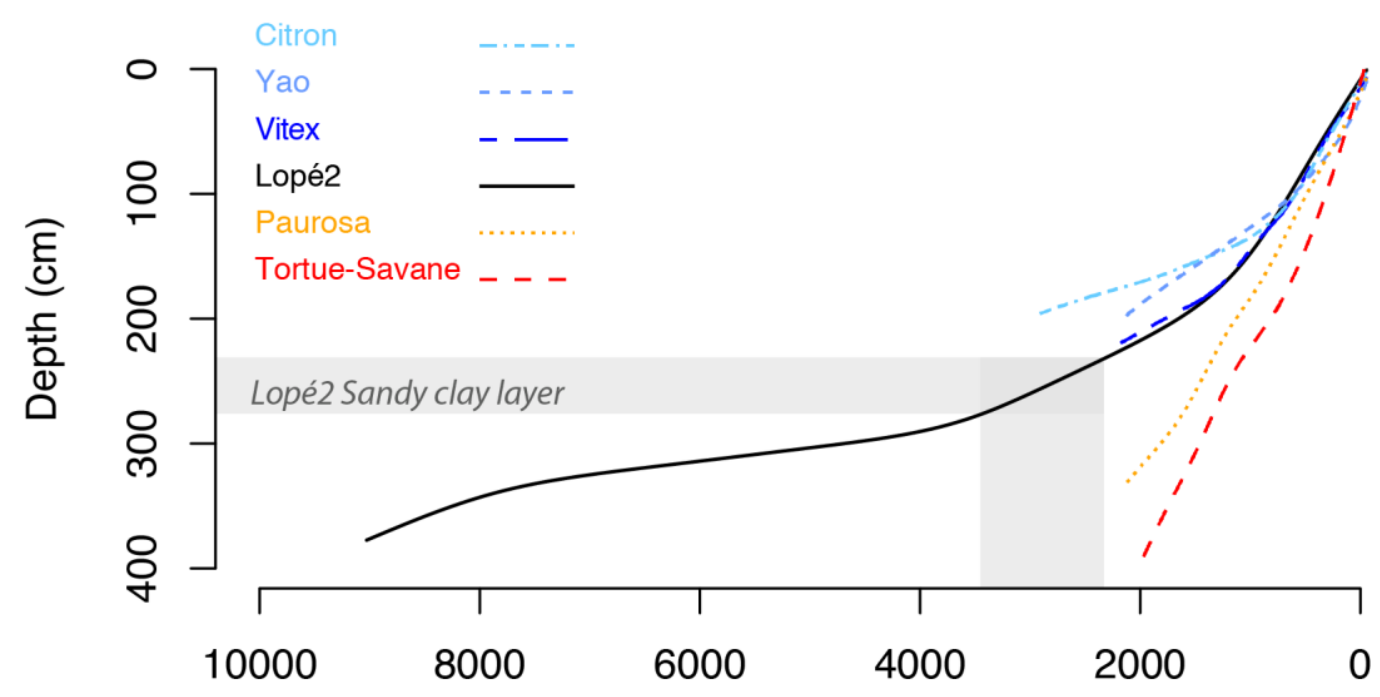

Age Cal. BP

Figure 5. Synthetic figure representing the age-depth models of the six studied marshes in Lopé National Park. 


\section{Geochemical characterization of the cores}

LOI-estimated organic matter trends follow those of elemental \%C measured by mass spectrometry (Figure SI 7. C\&OM). The percentage of $\mathrm{N}$ is low and the $\mathrm{C} / \mathrm{N}$ ratios for each core are always between 10 and 30, except for the two basal units of Lopé2, where it is consistently less than 10 (Figure SI 8. CvsN). $\mathrm{C} / \mathrm{N}$ ratios commonly range from 4 to 10 in algae-derived organic matter, while it is commonly greater than 20 in organic matter derived from vascular plants (Meyers and Teranes, 2001) however Nguetsop et al. (2013) reported $\mathrm{C} / \mathrm{N}$ ratios $<10$ on vascular terrestrial plants suggesting that caution must be taken when $\mathrm{C} / \mathrm{N}$ threshold is used to separate algae/vascular terrestrial organic carbon. Most organic matter of the studied sediments is then probably derived from vascular plants growing in and around the marshes (averaged $\mathrm{C} / \mathrm{N}$ ratios of the 6 cores varied between $16.0 \pm 2.9$ and $19.9 \pm 4.4$ ). The low values measured at Lopé2 below the sand layer can be interpreted as a higher proportion of organic matter produced by algae in permanent water conditions.

The XRF curves display similar patterns, although some elements have different absolute counts, because of the difference in OM content between the cores (Figure SI 5. XRF_OM_C_N). The PCA shows that $\mathrm{Si}, \mathrm{K}, \mathrm{Ti}, \mathrm{Al}$ vary in the same way and control the first eigenvector (> $65 \%$ of total variance). This is interpreted to represent detrital input associated with low OM content (Table 2). The second eigenvector $(10-20 \%)$ is controlled generally by S and Ca but they evolve independently (Figure SI 4. PCA on XRF data of the 6 cores).

Negative correlations between the C content (Table 1; see Figure SI 5. XRF_OM_C_N) and lithogenic $\mathrm{XRF}$ elements are consistent with a balance between plant derived deposits and soil derived sediments. However, there are not equivalent for all the elements in each marsh (Table 2). For example, $\mathrm{Al}$ is quite well correlated with the $C$ content in Yao, Tortue-Savane and Paurosa $\left(R^{2}=0,41, R^{2}=0,36\right.$ and $R^{2}=0,71$ respectively) when it is not correlated for the three other. But, $\mathrm{Si}$ is also correlated in Lopé2 in addition to Yao, Tortue-Savane and Paurosa. The correlations are less strong for Citron.

To synthesize, four major sediment types are differentiated in the cores collected from the 6 marshes. Common trends are emerging for Organic Matter, Carbon, Nitrogen, and XRF measurements (Figure SI 5. XRF_OM_C_N).

1) Clay/silt sediments, usually blue, are characterized by low $\mathrm{OM}$ and $\% \mathrm{C}$ values and positive scores on PCA first axis. This type of sediment is mainly found at the base of the longest cores: the deepest two meters of Tortue-Savane are very rich in clay with a greater organic fraction; at Paurosa, the whole base up to $1.5 \mathrm{~m}$ deep is very rich in clay with a gradual increase in the amount of OM; at Lopé2, the clay/silt sediments are brownish and become gradually blue as in the other cores.

2) A white sandy clay layer, more than $50 \mathrm{~cm}$ thick, only found in Lopé 2 is characterized by very low OM content (revealed both with the LOI and with \%C measured by spectrometry). XRF measurements record higher Si values for this part. The transition between this layer and the more organic gyttja type sediments above is accompanied by coarse sand. This coarse sandy portion was extracted at Lopé 2 and Vitex (it could be felt on the lower tip of the corer when sampling all the marshes). Axis 1 of the PCA shows well the transition between, white sandy clay layer, the coarse sandy layer and the more organic sediments above. In term of age, this layer corresponds to the base of the other cores.

\begin{tabular}{|c|c|c|c|c|c|c|c|c|c|c|c|c|c|c|c|c|c|c|c|}
\hline & \multicolumn{2}{|l|}{ Al } & \multicolumn{2}{|l|}{ Si } & \multicolumn{2}{|l|}{ 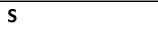 } & \multicolumn{2}{|l|}{ K } & \multicolumn{2}{|l|}{$\mathrm{Ca}$} & \multicolumn{2}{|l|}{$\mathrm{Ti}$} & \multicolumn{2}{|l|}{$\mathrm{Fe}$} & \multicolumn{2}{|l|}{$\mathbf{R h}$} & \multicolumn{3}{|c|}{ Axe 1 PCA } \\
\hline & $\mathrm{r}^{*}{ }^{*}$ & p-value & $\mathrm{r} 2^{*}$ & p-value & $\mathrm{r} 2^{*}$ & p-value & $\mathrm{r}^{*}$ & p-value & $\mathrm{r}^{*}$ & p-value & $r 2^{*}$ & p-value & $r 2^{*}$ & p-value & $r 2^{*}$ & p-value & $\mathrm{r}^{*}$ & & p-value \\
\hline VITEX & 0.27 & 0.001 & 0.3 & 0.001 & -0.03 & 0.823 & 0.29 & 0.001 & 0.01 & 0.279 & 0.35 & 0 & 0.36 & 0 & 0.23 & 0.003 & & 0.37 & $9.46 \mathrm{E}-05$ \\
\hline YAO & 0.41 & 0.002 & 0.36 & 0.005 & 0.26 & 0.019 & 0.11 & 0.099 & -0.05 & 0.728 & 0.17 & 0.049 & 0.34 & 0.006 & 0.27 & 0.016 & & 0.23 & 0.029243 \\
\hline CITRON & 0.19 & 0.01 & 0.19 & 0.011 & -0.03 & 0.63 & 0.16 & 0.019 & -0.01 & 0.447 & 0.13 & 0.029 & 0.14 & 0.027 & 0.04 & 0.139 & & 0.29 & 0.001798 \\
\hline TORTUE & 0.36 & 0.001 & 0.36 & 0.001 & -0.04 & 0.78 & 0.44 & 0 & -0.03 & 0.563 & 0.41 & 0 & 0.32 & 0.002 & 0.38 & 0 & & 0.35 & 0.000821 \\
\hline PAUROSA & 0.71 & 0 & 0.69 & 0 & 0.18 & 0.001 & 0.73 & 0 & 0.58 & 0 & 0.71 & 0 & 0.3 & 0 & 0.58 & 0 & D & 0.73 & $1.29 \mathrm{E}-15$ \\
\hline LOPE2 & 0.27 & 0 & 0.43 & 0 & 0.03 & 0.127 & 0.47 & 0 & 0.05 & 0.075 & 0.68 & 0 & 0.38 & 0 & 0.4 & 0 & D & 0.46 & $2.47 \mathrm{E}-07$ \\
\hline
\end{tabular}

Table 1. Correlation (adjusted $\mathbf{r}^{2}$ ) and $\mathrm{p}$-value (p) between elements and carbon content (\%) and for axe 1 pf the PCA. 


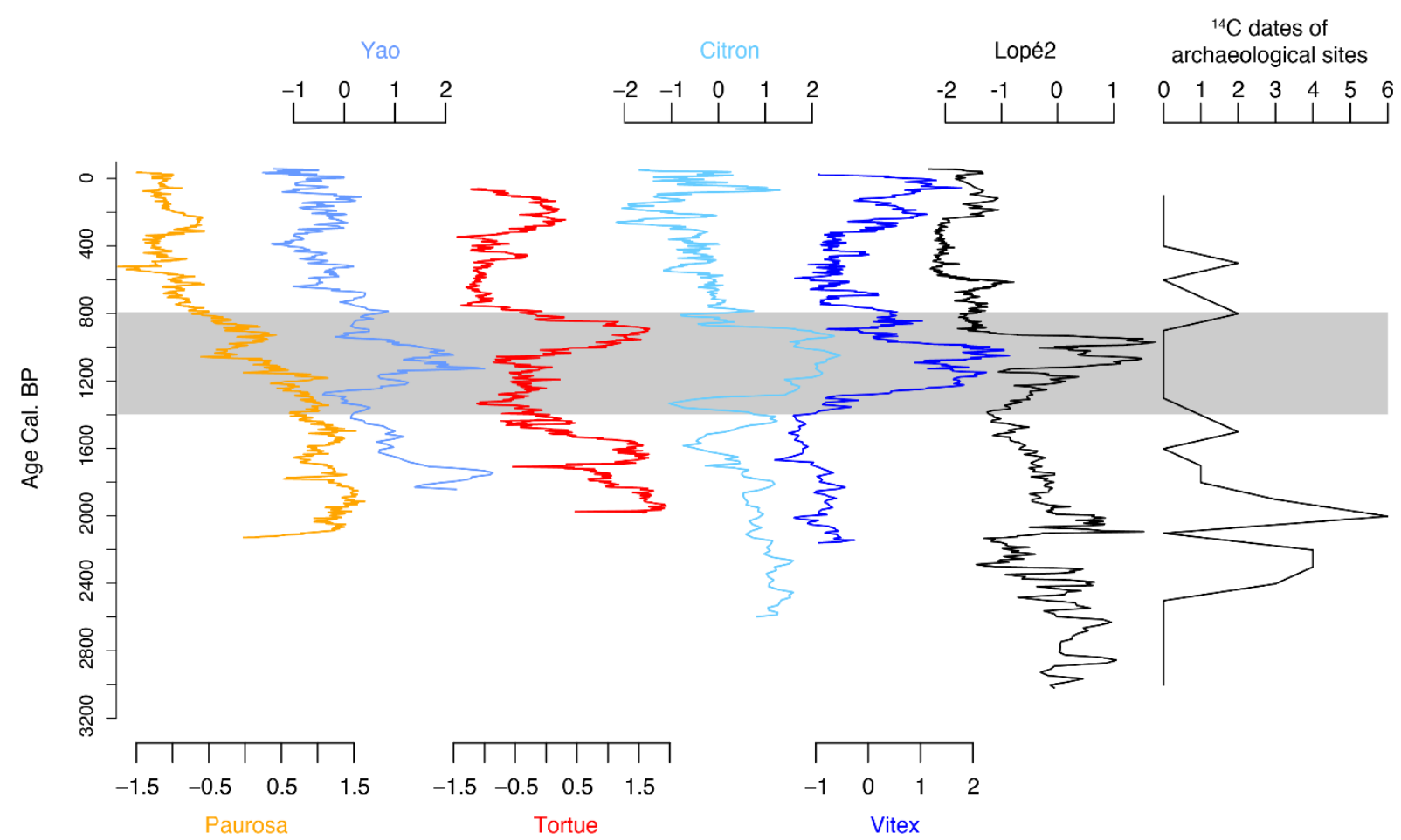

Figure 6. Time series plot of the first axe of Principal Components Analysis performed on the major elements measured by XRF. A 1400 to $800 \mathrm{cal}$ yr BP episode is highlighted in grey. Right panel represents the number of calibrated ${ }^{14} \mathrm{C}$ dates from archaeological sites in the region (after Oslisly et al., 2013).

3) Peaty Gyttja deposits are found above the clayey sediments at Tortue-Savane, Paurosa, and Lopé2 with a transition of clayey gyttja which also forms the basis for Vitex and Citron. The peaty deposits result in a large amount of OM. XRF analyses indicate higher values of $\mathrm{Ti}, \mathrm{Fe}, \mathrm{K}$, and $\mathrm{Al}$.

4) Fibrous peaty deposits are found at the top of the cores; they correspond to very little degraded, recent plant remains.

The PCA performed on the elements permit to emphasize the signal record by the XRF data and allow a comparison between marshes. Figure 6 shows that a period marked by an increase of the mineral fraction between 1400 and $800 \mathrm{cal} \mathrm{yr} \mathrm{BP}$ is well recorded in all the marshes except for Paurosa. In Paurosa, this increase is less visible, probably because of the strong trend forced by the $C$ content along the sediment core. Indeed, there is good correlation between Axe 1 of the PCA and the C content within Paurosa and to a lesser extent, in Lopéz and Tortue-Savane (Table 2 and raw data in SI "Data\#BREMOND2021). This phase between 1400 and 800 is not easily detectable with the lithology alone because whereas the majority of the cores presents deposits of clayey gyttja or gyttja clay layers during this event, peaty gyttja is also deposited in Tortue-savane and a fine layer of clay/silt blue is deposited in Paurosa (Figure 5).

The increase in the mineral fraction revealed by the XRF analyses coincides with an absence of archaeological dating around the NLP zone $\left(5^{\circ} \mathrm{S}\right.$ to $5^{\circ} \mathrm{N} \& 7^{\circ} \mathrm{E}$ to $\left.17^{\circ} \mathrm{E}\right)$. Dates are mainly from charcoals found associated with archaeological remains (see Oslisly et al., 2013 for details).

\section{Stable isotope composition}

The $\delta^{13} \mathrm{C}$ signal from bulk sediment of the six cores vary greatly from values characterizing $\mathrm{C}_{3}-$ dominated vegetation to values characterizing almost pure $\mathrm{C}_{4}$ plant production (Figure 7). For the marshes that are located today in savanna, the common general trend is a decrease from a $\mathrm{C}_{4}$ pole at the base of the cores to a $C_{3}$ dominated signal towards the tops. ${ }^{13} C$ signal of Lopé2, the only marsh in the 


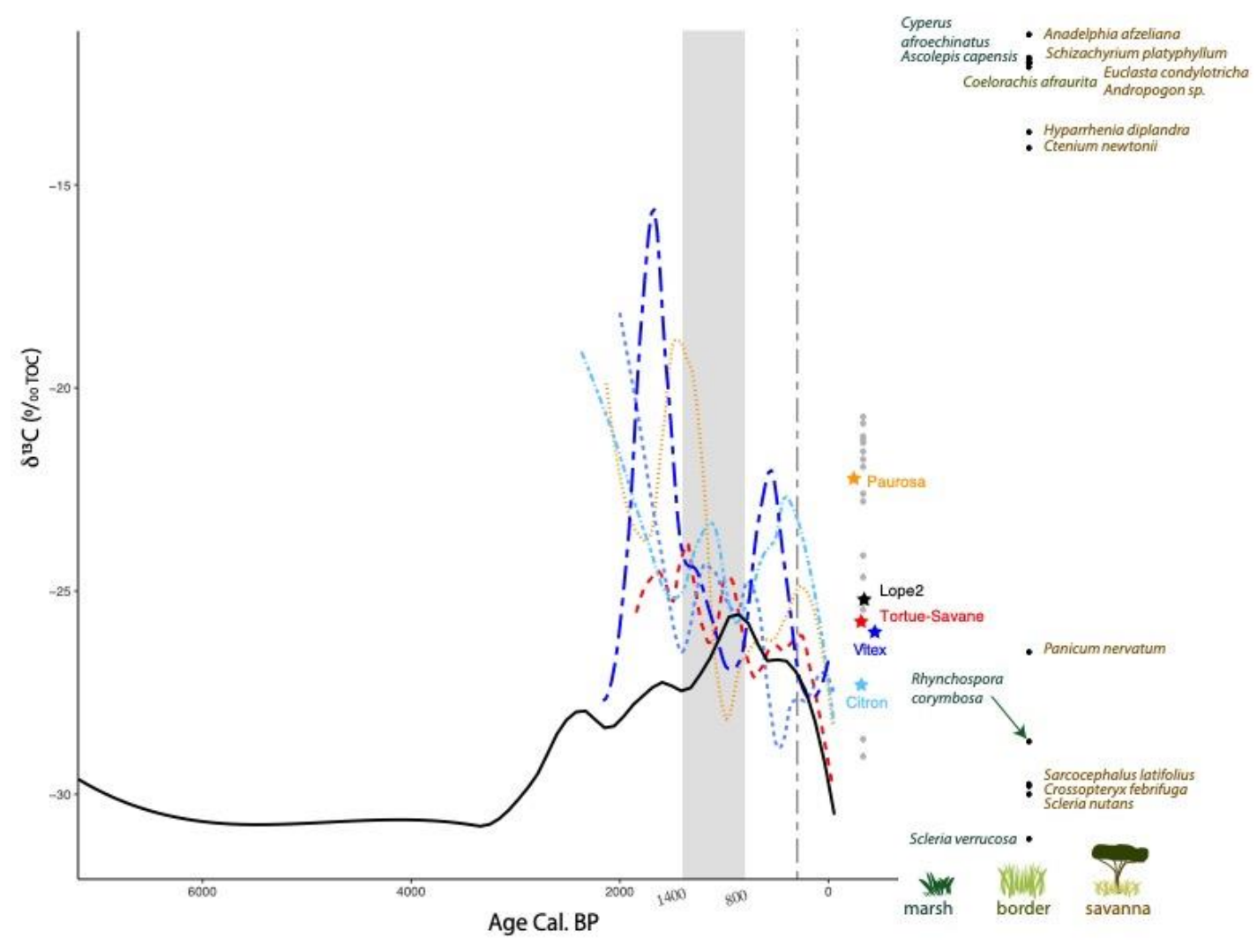

Figure 7. Bulk ${ }^{\circ}{ }^{13} \mathrm{C}$ values of the six studied sediment cores (color lines) and main plants growing around or on the marshes (black dots). The modern values (stars on the right of the curves and grey dots) are measured on marsh surface sediments by collecting and mixing 20 subsamples from the whole surface of the marsh.

forest, changes from a pure $\mathrm{C}_{3}$ pole $(-30 \%$ o) to a less negative isotopic $\mathrm{C}$ composition after the sand layer, 3500-2300 cal yr BP, but never exceeds $-24.5 \%$.

For Vitex and Paurosa, highest values (-15\%o and $-17 \%$ o) are reached respectively at 1600 and 1500 cal yr BP. The upper parts of all the cores display a decrease of $\delta^{13} \mathrm{C}$ from $-25 \%$ o to $-28 \%$ o to almost $-30 \%$. The top of the cores have generally lower values compared with the surface marshe samples that vary between $-22 \%$ on Vitex and $-29 \%$ on Tortue-Savane. For the plants two $\delta^{13} \mathrm{C}$ poles are observed, from 16 to -12 and from -36 to $-27 \%$.

The $\delta^{15} \mathrm{~N}$ presents values between 0 and $7 \%$ ofor all the cores but the majority of the measures are between 1 to $4 \%$ o (Figure SI 9. $15 \mathrm{~N}$ ). As the $\delta^{13} \mathrm{C}$ signal, there is no obvious common inter-site signal. There is, however, a tendency for values to cluster around 2 at the top of the cores, in the same way that the $\delta^{13} \mathrm{C}$ decreases at the top of cores.

\section{Discussion}

\section{Intra and inter variability of the signals recorded by the marshes}

Analyses of two cores in several marshes in a restricted geographical setting offered the opportunity to: 1) estimate the consistency between signals in cores from the same marsh and then elucidate the possibility to consider tropical marsh sediment cores as reliable paleoenvironmental archives; 2) differentiate which signals are purely local, related to each marsh, and which are representative at the landscape scale. Each proxy should have its own measurement sensitivity. First, XRF data are generally used to estimate changes in the type of clastic material related to physical weathering (Arnaud et al., 
2012). Very few studies have concerned tropical wetlands but Chawchai et al. (2016) showed that XRF data are well related to sediment grain size and C content. Likewise, in our study, the signals recorded within the same marshes are quite similar, despite two different XRF sensors, on two different cores a few meters away (Figure SI 3. XRF alignment). As opposed to lake sediments, in which we can expect good similarity (Hatfield et al., 2020), the mode of deposition in peat bogs, i.e. high spatial variability on a very small scale, and the high water content of the sediments impact the quality of XRF measurements (Longman et al., 2019). However, in spite of this, we think that the XRF signals between the two sets of our cores from the same marsh are very consistent with each other. Carbon isotopic analyses performed on a third core sampled in Paurosa by Obame (unpublished thesis 2019) show similar signals as we performed in our core. Also, the marshes we studied show no evidence of animal disturbance, the XRF analyses and radiocarbon dating confirmed that, and this has probably been so for over 2000 years. Conversely, radiocarbon dates performed on a section of another marsh dug by animals now have presented inversions (Oslisly unpublished data). This suggests that there is a recurrence choice of wild animals in the long term. These points out a low intra-marsh variability and, therefore, confirm that small sedge marshes are good natural archives for equatorial environments.

However, inter-marsh variability between the six marshes is more complex. Differences between sites indicate that the internal functioning of each marsh has a greater impact than external forcings on the signals recorded by the proxies. It is also likely that this effect may be very different depending on each proxy. For instance, the lithology succeed in the same order, but change of facies occur at different depths and age in each marsh. This heterogeneity results in differences in XRF signals. In the same way, the signals recorded by the $\delta^{13} \mathrm{C}$, as the $\delta^{15} \mathrm{~N}$, along the different cores do not display clearly synchronized changes because of the local drivers of each marsh. $\delta^{13} \mathrm{C}$ signal integrates a mixture of organic matter from different origins with different isotopic composition. Catchment area inputs, associated with the edge of the marsh, mixes with in situ production. The latter comprises a $C_{3}$ pole produced by the sedge Rhynchospora, and a $\mathrm{C}_{4}$ pole produced by the Poaceae that can colonize the marsh when it is drier. This explains is why surface samples have a wide range of $\delta^{13} \mathrm{C}$ values, depending on the proportion of herbaceous plants growing on the marsh. The negative shift in $\delta^{13} \mathrm{C}$ between core tops and surface samples is easily explained. In addition to the Suess effect which decreases the values of the post-industrial $\delta^{13} \mathrm{C} \mathrm{CO}_{2}$ and consequently of plants (Keeling, 1979) and the likely $\delta^{13} \mathrm{C}$ and $\delta^{15} \mathrm{~N}$ but small enrichment (Rayleigh fractionation) during the early diagenesis processes (Talbot and Johannessen, 1992) the cores were systematically collected in the wettest part of the marshes, where only $C_{3}$ Rhyncospora grows ( $\delta^{13} \mathrm{C}$ of the peats from $-25 \%$ o to $-28 \%$ ), while surface samples integrate the whole marsh areas and reflect the presence of $\mathrm{C}_{4}$ Poaceae in some parts. Today, Poaceae invade marshes when they dry out long enough during the year. In these marshes, $\delta^{13} \mathrm{C}$ can therefore be considered as an indicator of local moisture conditions. A recent study on pollen surface samples of the same marshes confirms that the local functioning has also a significant influence on the pollen assemblages (HengaBotsikabobe et al., 2020). Differentiating between in situ production and catchment area inputs would require an independent proxy, such as pollen and phytoliths, with the ability to estimate the vegetation that constitutes the marsh (Henga-Botsikabobe et al., 2020) and the tree cover of the savanna (Bremond et al., 2005) and thus the variations of extra-local inputs through time.

The interpretation of the $\delta^{15} \mathrm{~N}$ signal is not obvious because we are not aware of any study that has attempted to interpret the signal in the same type of environmental context. However, when comparing variations in $\delta^{15} \mathrm{~N}$ at Paurosa with diatom assemblages published by Kom et al. (2018) it would appear that $\delta^{15} \mathrm{~N}$ has the highest values when benthic diatoms dominate. Kom et al. (2018) interpret the base of the sequence as a phase with shallow water depth, a nutrient-poor environment and marked dry seasons. This is in agreement with Swap et al. (2004) study showing a decrease of $\delta^{15} \mathrm{~N}$ of southern African vegetation with precipitation increase. The $\delta^{15} \mathrm{~N}$ values decrease in the same way as the axis 1 of the PCA and the amount of OM. These changes are probably linked to the balance of nitrogen inputs from land plants and soils with $\delta^{15} \mathrm{~N}$ values between 2 to 10 and aquatic macrophytes that have lower values (Meyers and Teranes, 2001) plus nitrification during dry phases. Finally, the negative shift in $\delta 15 \mathrm{~N}$ in the core tops may be related to a "15N Haber-Bosch effect" in analogy to the "13C Suess effect" 
(Yang and Gruber, 2016) and would add to the Rayleigh fractionation during the early diagenesis processes of organic matter.

\section{Setting up of the marshes and sedimentation records}

The oldest sequence sampled in the studied site is the Lopé2 core with nearly 9,000-year-old sediment at its base. The bottom part of the core consists of clay/silt sediments and contains little highly decomposed and oxidized OM (Obame et al., 2017). This corresponds to deposits from a temporary pool, i.e. a water body that intermittently dries. In line with this interpretation, the sedimentation rate is far lower than in the upper part and the mineralogical composition more closely resembles that of soils than that of lacustrine deposits (high $\mathrm{Al}, \mathrm{Fe}$, and Ti content). Above these clay/silt sediments, a layer of sandy/clay, at least $40-\mathrm{cm}$ thick, was deposited. In the other marshes, this sandy/clay layer was not collected probably because manual handing of the Russian corer does not allow sinking into too much consolidated layers. Initial survey of the depths with an iron rod confirms the presence of a sandy layer in all the marshes. In one of them, a small stream cut and eroded the peat in the outlet of the marsh and exposed this layer, visibly made of gravels and white sand and sandy/clay layer (see Annexe Photo "Cross section marsh" and Lopé2 Photography and Log). In Lopé2, just under the sandy/clay layer, a carbonized plant fragment and bulk sediment were radiocarbon dated at $3500 \mathrm{cal} \mathrm{yr} \mathrm{BP}$ and 3800cal yr $\mathrm{BP}$, respectively. Right on top of the sand layer, a seed was dated around $2100 \mathrm{cal} \mathrm{yr} \mathrm{BP.} \mathrm{According} \mathrm{to}$ these dates that frame the sandy/clay layer, the age model estimates that the sedimentation rate remains constant, ruling out the possibilities of a hiatus of chronological deposits or of a drastic erosion event with rapid deposits. The sandy/clay layer, dated at Lopé2 between 3450 and $2300 \mathrm{cal} \mathrm{yr}$ BP corresponds to the period of surface deposits called the "Stone Line event" (c.3500-2800 cal yr BP) and part of the "Cover Horizon" (c. 2800-2000 cal yr BP) by Thiéblemont et al $(2013,2014)$. Without seeking to discuss the aeolian or colluvial origin of this layer, we cannot retain the conclusion of the authors that Gabon and western Congo was free of forest c. 4000 to 2000 BP due to our results and others elsewhere in Central Africa (Bremond et al., 2017; Maley et al., 2014) but the grainsize of sandy/clay layer corresponds well with this "Cover Horizon" (Thiéblemont et al., 2014). The coarse sand layer found in Lopé2 above the sandy/clay layer, at the base of Vitex and probably in all the marshes can originate from an increase in the hydrodynamic conditions of the basin and the filling up of the depression by small riverbeds replacing the seasonally flooded depression. This assumption does not imply strong external forcing, such as a major change in the tree-covered directly around the basin. Preliminary pollen analyses have recorded taxa of disturbed environments without vegetation opening around the marsh (HengaBotsikabobe et al. in prep). A shift in the hydrological budget is consistently observed in tropical Africa about 4000 years ago (Marchant and Hooghiemstra, 2004), at the African Humid Period termination close to the equator (Phelps et al., 2020; Shanahan et al., 2015). This period would be climatically characterized by greater precipitation seasonality (Peyrot et al., 2003) and strong rainfalls (Maley et al., 2018; Thiéblemont, 2013). Lopé2, as well as all other marshes that have significantly accumulated sediment, are located on the foothills of the little mountain range (see Figure 1). It is likely that during this period, alluvium from this topography increased and the sand, as the coarsest component of the deposits, remained while the finer fractions were washed away by water. It is also likely that the ferrous oxides that color the "Cover Horizon" layer were also exported by leaching making the layer white and not yellow as it is visible in the region (Thiéblemont, 2013). This would explain the presence of a sand layer at the base of each sedimentary sequence in the marshes studied. There is probably no older sediment under this layer in most of the marshes of the LNP, except in Lopé2, which is among the largest and deepest, is one the few that have the topographical characteristics for the establishment of a real little lake before this episode.

After this phase with particular hydrological conditions, it is conceivable that the rainfall seasonality and the annual amount of precipitations that we are experiencing today may have set in. The topographical disposition of the marshes on a continuous flat surface in the savanna area indicates that annual rainfall sufficiently fed the water table to maintain conditions wet enough to preserve OM in all the studied marshes and to avoid sedimentation hiatus. The lithological resemblance between all 
sediment cores indicates a common history of the development of the marshes in LNP. Clayey/peaty gyttja with plant remains dated at $2000 \mathrm{cal} \mathrm{yr} \mathrm{BP} \mathrm{(+-} 200$ years) overlay this sand layer within all the marshes (in Tortue-Savane and Paurosa the sediment is more clayey). A previous study in two other marshes provided consistent dates of a wood piece (1688- 1824 cal yr BP), a palm nut (1715 -1953 cal yr BP), and a wood charcoal (1709-2000 cal yr BP), immediately above an approximately 10-cm-thick sand and gravel layer (Oslisly and White, 2000).

At the early stages of marsh functioning, the sediment is clayey and poorly organic, and the $\delta^{13} \mathrm{C}$ signals record that significant proportion of $\mathrm{OM}$ originates from $\mathrm{C}_{4}$ species except in Lopé2 where there is a slight increase. This indicates that the environment was already open with $C_{4}$ savanna herbs whose signature registers in the sediments because there were not yet any plants growing directly in the marsh. Afterwards, the observed decrease in $\delta^{13} \mathrm{C}$ as the organic fraction increases in sediment can result from the colonization of marshes by $\mathrm{C}_{3}$ aquatic plants such as the sedges Rhyncopospora, which dominates marshes where water is permanent all year round.

Finally, most marshes start between 1950 and 2150 years ago, after the African Humid Period termination in the region (Shanahan et al., 2015) but also a few hundred years after the arrival of the ironworkers (Oslisly, 2001). Nowadays the climatic conditions are favorable to the colonization of forest over savanna, which is observed in zones without a high frequency of fires (Jeffery et al., 2014). If we consider that the climatic conditions were much the same as today, it is conceivable that, if Human did not trigger the sedimentation in the lowlands, they contributed to it by maintaining an open environment and preventing the forest from colonizing these wetlands and make these natural archives disappear. Finally, what we observe here, at the very local scale, echoes the hypotheses made by Phelps et al. (2020) at the global scale of Africa about the influence of anthropogenic disturbance on vegetation change since the termination of the AHP.

\section{The 1400-800 years cal. BP episode}

The relative increase of mineral fraction between 1400 and $800 \mathrm{cal} \mathrm{yr} \mathrm{BP}$ recorded in all the cores suggests that a common external forcing affected the deposits of all the marshes, concomitantly with a hiatus of human occupation evidenced by the absence of archaeological sites dated from this interval in the LNP (Oslisly, 2001). Such a shift of the organic-mineral balance towards mineral elements may have originated from either an increase of mineral inputs, related to an increase of erosion in the surrounding basins due to a change in the rainfall regime and/or in the vegetation cover. Alternatively, it may have resulted from post-deposition increased mineralization of organic matter under oxidizing conditions related to a drying of the marshes. Rock-Eval pyrolysis analyses in another core sampled in Lopé2 indeed evidenced more decomposed organic matter around $175 \mathrm{~cm}$ depth, about almost 1200 years cal yr BP (Obame et al.,2017). This episode corresponds to the base of the sediments in lake Kamalété in the south of the LNP (Ngomanda et al., 2005) in which the mineralogy would be associated to long dry season length and irregular rainfalls (Giresse et al., 2009). There, dominance the pollen assemblages shifts around $1300 \mathrm{cal} \mathrm{yr} \mathrm{BP}$ from mature forest taxa, (i.e. Celtis, Caesalpiniaceae, Mimosaceae) to pioneer arboreal taxa (e.g., Tetrorchidium, Macaranga, Musanga, Alchornea and Elaeis guineensis) characterizing a disturbed semi-evergreen rainforest (Ngomanda et al., 2007). A change of the rainfall regime leading to a drying-up of the marshes would explain the increase in mineral fraction in the marshes and the increase in indicators of disturbance in the pollen reconstructed floristic cortege. Concurrent lack of evidence of human activity, not only in LNP but consistently throughout the forest hinterland of West Central Africa (Garcin et al., 2018; Oslisly et al., 2013) would be likely related to this regional climate change. Unfavorable climatic conditions may have led to the decline or migration of populations or specific environmental conditions may have been favored pathogen emergence (Sebag et al., 2016).

Traces of human activity are difficult to identify in the sediments. These are generally indirect evidence and generate much debate since climate change can have the same outcomes on vegetation proxies (Garcin et al., 2018; Giresse et al., 2018). This is typically the case here since the forest shows signs of degradation when there is little or no human activity. 


\section{Conclusion}

This study highlights the interest peat deposits of tropical marshes in savanna as archives for long-term ecology research. The sedimentation within a marsh is homogenous with low intra-site variability of the elemental data through XRF measurements. This means that a single core taken from the center, where there is the highest deposition of sediment, should be representative of the entire marsh.

In contrast, the variability between the sites is very high, which shows the major role played by the functioning of the marsh itself. This is likely constrained by the topography, the catchment shape, and the seasonal moisture conditions. However, major regional events that sufficiently affect all watersheds are still recorded in every marsh. It will be interesting to see how the different bio-proxies used traditionally in paleoecology respond, since each has different sources and deposition patterns.

Finally, what appears to be a regional phase is recorded between 1400 and 800 years ago, at the same time an archaeological trace hiatus is observed throughout the forest hinterland of West Central Africa. This episode, well known in archeology would be interesting to study with a paleo-ecological approach to reconstruct the environmental conditions and climate changes of the time and enable understanding of the mechanisms that led to population declines.

\section{Acknowledgments}

Fieldwork was supported by grants from the University of Rouen, SCALE Research Federation, French Embassy at Libreville ("Service de Coopération et d'Action Culturelle"), EPHE and the French National Research Institute for Sustainable Development (IRD). This study was also supported by ANPN and IRD through LMC14 laboratory (CEA-CNRS- IRD-IRSN-MCC, France) that provided the ${ }^{14} \mathrm{C}$ analyses, Logistical support was provided by the National Agency for National Parks (ANPN, Libreville, Gabon), WCS (Libreville, Gabon) and CEDAMM (National Park, Lopé, Gabon), Research Station on Gorilla and Chimpanzee (SEGC, Gabon), and "Agence Universitaire de la Francophonie" (AUF). We also thank the institutions that made this project possible: CENAREST for research authorizations, IRET and IRAF (Libreville, Gabon), University of Science and Technology in Masuku (Franceville, Gabon), CIRMF (Franceville, Gabon) and Omar Bongo University (Libreville, Gabon). We are grateful to Laure Paradis for extracting satellite data and mapping the field of study and François Fourel to having prepared and measured the C\&N isotopes of the leaves and surface sediments. We warmly thank Benoit Devillers for lending us the Innov-X XRF portable analyzer. We thanks also Daryl Codron for giving us unpublished data of $\delta^{13} \mathrm{C}$ values from fresh plants. Thanks to Denis Thiéblemont and another anonymous reviewer for their very constructive reviews.

\section{References}

Arnaud F, Révillon S, Debret M, Revel M, Chapron E, Jacob J, et al. (2012) Lake Bourget regional erosion patterns reconstruction reveals Holocene NW European Alps soil evolution and paleohydrology. Quaternary Science Reviews 51: 81-92.

Barber K, Dumayne-Peaty L, Hughes P, Mauquoy D and Scaife R (1998) Replicability and variability of the recent macrofossil and proxy-climate record from raised bogs: field stratigraphy and macrofossil data from Bolton Fell Moss and Walton Moss, Cumbria, England. Journal of Quaternary Science 13(6): 515-528.

Bayon G, Schefuß E, Dupont L, Borges AV, Dennielou B, Lambert T, et al. (2019) The roles of climate and human land-use in the late Holocene rainforest crisis of Central Africa. Earth and Planetary Science Letters 505: 30-41.

Blaauw M and Christen JA (2011) Flexible paleoclimate age-depth models using an autoregressive gamma process. Bayesian Analysis 6(3): 457-474.

Boulvert Y and Salomon J-N (1988) Sur l'existence de paléo-crypto karsts dans le bassin de l'Oubangui (République centrafricaine). Karstologia 11(1): 37-48.

Bremond L, Alexandre A, Hély C and Guiot J (2005) A phytolith index as a proxy of tree cover density in tropical areas: calibration with Leaf Area Index along a forest-savanna transect in southeastern Cameroon. Global and Planetary Change 45(4): 277-293.

Bremond L, Bodin S, Bentaleb I, Favier C and Canal S (2017) Past tree cover of the Congo Basin recovered by 
phytoliths and $\delta 13 \mathrm{C}$ along soil profiles. Quaternary International 434: 91-101.

Caporale AG, Adamo P, Capozzi F, Langella G, Terribile F and Vingiani S (2018) Monitoring metal pollution in soils using portable-XRF and conventional laboratory-based techniques: Evaluation of the performance and limitations according to metal properties and sources. Science of The Total Environment 643: 516-526.

Chawchai S, Kylander ME, Chabangborn A, Löwemark L and Wohlfarth B (2016) Testing commonly used X-ray fluorescence core scanning-based proxies for organic-rich lake sediments and peat. Boreas 45(1): 180-189.

Descoing B (1974) Notes de phyto-écologie équatoride. 2. Les formations herbeuses du Moyen-Ogooué (Gabon). Candollea 29: 13-37.

Dumoulin J-P, Comby-Zerbino C, Delqué-Količ E, Moreau C, Caffy I, Hain S, et al. (2017) Status Report on Sample Preparation Protocols Developed at the LMC14 Laboratory, Saclay, France: From Sample Collection to 14C AMS Measurement. Radiocarbon 59(3): 713-726.

Gajewski K (2008) The Global Pollen Database in biogeographical and palaeoclimatic studies. Progress in Physical Geography 32(4): 379-402.

Garcin Y, Deschamps P, Ménot G, Saulieu G de, Schefuß E, Sebag D, et al. (2018) Early anthropogenic impact on Western Central African rainforests 2,600 y ago. Proceedings of the National Academy of Sciences 115 (13): 201715336.

Gavin DG (2001) Estimation of inbuilt age in radiocarbon ages of soil charcoal for fire history studies. Radiocarbon 43(1): 27-44.

Giresse P, Makaya Mvoubou, Maley J and Ngomanda A (2009) Late-Holocene equatorial environments inferred from deposition processes, carbon isotopes of organic matter, and pollen in three shallow lakes of Gabon, westcentral Africa. Journal of Paleolimnology 41(2): 369-392.

Giresse P, Maley J, Doumenge C, Philippon N, Mahé G, Chepstow-Lusty A, et al. (2018) Paleoclimatic changes are the most probable causes of the rainforest crises 2,600 y ago in Central Africa. Proceedings of the National Academy of Sciences 115(29): E6672-E6673.

Goslar T, Czernik J and Goslar E (2004) Low-energy 14 C AMS in Poznań Radiocarbon Laboratory, Poland. Nuclear Instruments and Methods in Physics Research Section B: Beam Interactions with Materials and Atoms 223: 5-11.

Hatfield RG, Woods A, Lehmann SB, Weidhaas N, Chen CY, Kück J, et al. (2020) Stratigraphic correlation and splice generation for sediments recovered from a large-lake drilling project: an example from Lake Junín, Peru. Journal of Paleolimnology 63(1): 83-100.

Hatté C (2000) Les isotopes du carbone 14c et 13c dans la matiere organique des loess de l'europe du nord-ouest: applications paleoclimatiques - PhD Thesis. Paris, Université Paris XI.

Heiri O, Lotter AF and Lemcke G (2001) Loss on ignition as a method for estimating organic and carbonate content in sediments: reproducibility and comparability of results. Journal of Paleolimnology 25(1): 101-110.

Hély C and Lézine AM (2013) Holocene changes in African vegetation: tradeoff between climate and water availability. Climate of the Past Discussions 9(6).

Henga-Botsikabobe K, Ngomanda A, Oslisly R, Favier C, Muller SD and Bremond L (2020) Modern pollenvegetation relationships within tropical marshes of Lopé National Park (Central Gabon). Review of Palaeobotany and Palynology 275: 104168.

Holmquist JR, Finkelstein SA, Garneau M, Massa C, Yu Z and MacDonald GM (2016) A comparison of radiocarbon ages derived from bulk peat and selected plant macrofossils in basal peat cores from circum-arctic peatlands. Quaternary Geochronology 31: 53-61.

Jackson ST (1990) Pollen source area and representation in small lakes of the northeastern United States. Review of Palaeobotany and Palynology 63(1): 53-76.

Jacobson GL and Bradshaw RH (1981) The selection of sites for paleovegetational studies. Quaternary Research 16(1): 80-96.

Jeffery KJ, Korte L, Palla F, Walters GM, White L and Abernethy K (2014) Fire management in a changing landscape: a case study from Lopé National Park, Gabon. Parks 20(1): 35-48.

Keeling CD (1979) The Suess effect: 13Carbon-14Carbon interrelations. Environment International 2(4): 229-300.

Kom MF, Nguetsop VF, Bremond L, Fonkou T, Noumsi B, Sebag D, et al. (2018) Evolution paléohydrologique du marais Paurosa au centre du Gabon au cours des deux derniers millénaires: Contribution des diatomées. Cameroon Journal of Experimental Biology. Dschang University Press 12(1): 65-78.

Lézine A-M, Hély C, Grenier C, Braconnot P and Krinner G (2011) Sahara and Sahel vulnerability to climate changes, lessons from Holocene hydrological data. Quaternary Science Reviews 30(21): 3001-3012.

Ligges U and Mächler M (2002) Scatterplot3d - an R package for visualizing multivariate data. Working Paper. Technical 
Report, SFB 475: Komplexitätsreduktion in Multivariaten .... Available at: https://www.econstor.eu/handle/10419/77160.

Lisiecki LE and Lisiecki PA (2002) Application of dynamic programming to the correlation of paleoclimate records. Paleoceanography 17(4): 1-1-1-12.

Longman J, Veres D and Wennrich V (2019) Utilisation of XRF core scanning on peat and other highly organic sediments. Quaternary International 514: 85-96.

Maley J, Doumenge C, Giresse P, Mahé G, Philippon N, Hubau W, et al. (2018) Late Holocene forest contraction and fragmentation in central Africa. Quaternary Research 89(1): 43-59.

Maley J, Giresse P, Favier C and Doumenge C (2014) Comment on “Geochronological arguments for a close relationship between surficial formation profiles and environmental crisis (c. 3000-2000 BP) in Gabon (Central Africa)", by D. Thiéblemont et al., 2013 [C.R. Geoscience 345, 272-283]. Comptes Rendus Geoscience 346(7-8): 200202.

Marchant R and Hooghiemstra H (2004) Rapid environmental change in African and South American tropics around 4000 years before present: a review. Earth-Science Reviews 66(3): 217-260.

Meyers PA and Teranes JL (2001) Sediment Organic Matter. In: Last WM and Smol JP (eds) Tracking Environmental Change Using Lake Sediments: Physical and Geochemical Methods. Dordrecht: Springer Netherlands, 239-269. Available at: https://doi.org/10.1007/0-306-47670-3_9.

Ngomanda A, Chepstow-Lusty A, Makaya M, Schevin P, Maley J, Fontugne M, et al. (2005) Vegetation changes during the past 1300 years in western equatorial Afnrca: a highresolution pollen record from Lake Kamalete, Lope Reserve, Central Gabon. The Holocene 15(7): 1021-1031.

Ngomanda A, Jolly D, Bentaleb I, Chepstow-Lusty A, Maley J, Fontugne M, et al. (2007) Lowland rainforest response to hydrological changes during the last 1500 years in Gabon, Western Equatorial Africa. Quaternary Research 67(3): 411-425.

Nguetsop VF, Bentaleb I, Favier C, Bietrix S, Martin C, Servant-Vildary S, et al. (2013) A late Holocene palaeoenvironmental record from Lake Tizong, northern Cameroon using diatom and carbon stable isotope analyses. Quaternary Science Reviews 72: 49-62.

Nilsson M, Klarqvist M, Bohlin E and Possnert G (2001) Variation in 14C age of macrofossils and different fractions of minute peat samples dated by AMS. The Holocene. SAGE Publications Ltd 11(5): 579-586.

Obame VN (2019) Comblements et paléoenvironnements fini-Holocènes des Marais du Parc National de La Lopé. Gabon, Université des Sciences et Techniques de Masuku.

Obame VN, M'voubou M, Sebag D, Bremond L, Mounguengui MM and Giresse P (2017) Le rôle de l'évolution des paysages holocènes dans le comblement des bas-fonds du Parc national de la Lopé, moyenne vallée de l'Ogooué au Gabon. Bois et Forêts des Tropiques 333(0): 67-77.

Oslisly R (2001) The history of human settlement in the middle Ogooué valley (Gabon) Implications for the environment. African rain forest ecology and conservation. New Haven and London: Yale University Press, 101-118.

Oslisly R, Bentaleb I, Favier C, Fontugne M, Gillet JF and Morin-Rivat J (2013) West Central African Peoples: Survey of Radiocarbon Dates over the Past 5000 Years. Radiocarbon 55(3): 1377-1382.

Oslisly R and White L (2000) La relation homme/milieu dans la réserve de la Lopé (Gabon) au cours de l'Holocène; les implications sur l'environnement. Diversité actuelle de la forêt tropicale et changements passés du climat : le programme Ecosystèmes et paléoécosystèmes des forêts intertropicales (ECOFIT) : bilan et perspectives. Paris: IRD, 241-250. Available at: http://www.documentation.ird.fr/hor/fdi:010054546.

Peyrot B, Oslisly R, Abdessadok S, Fontugne M, Hatte C and White L (2003) Les paléoenvironnements de la fin du Pléistocène et de l'Holocene dans la réserve de la Lopé (Gabon): approche par les indicateurs géomorphologiques, sédimentologiques, phytologiques, géochimiques et anthropogènes des milieux enregistreurs de la dépression de la Lopé. L'Anthropologie 107(2): 291-307.

Phelps LN, Chevalier M, Shanahan TM, Aleman JC, Courtney-Mustaphi C, Kiahtipes CA, et al. (2020) Asymmetric response of forest and grassy biomes to climate variability across the African Humid Period: influenced by anthropogenic disturbance? Ecography (43): 1-26.

Reimer PJ, Bard E, Bayliss A, Beck JW, Blackwell PG, Ramsey CB, et al. (2013) IntCal13 and Marine13 Radiocarbon Age Calibration Curves 0-50,000 Years cal BP. Radiocarbon 55(4): 1869-1887.

Sebag D, Bremond L, Jeffery KJ, Nguetsop F, Oslisly R, Oszwald J, et al. (2016) Le rôle des bas-fonds dans l'évolution des paysages du Parc National de la Lopé. In: Saulieu G de, Elouga M and Sonké B (eds) Pour une écologie historique en Afrique centrale. Yaoudé: AUF, 141-155. Available at: http://www.documentation.ird.fr/hor/fdi:010069872. 
Shanahan TM, McKay NP, Hughen KA, Overpeck JT, Otto-Bliesner B, Heil CW, et al. (2015) The time-transgressive termination of the African Humid Period. Nature Geosci 8(2): 140-144.

Swap RJ, Aranibar JN, Dowty PR, Gilhooly WP and Macko SA (2004) Natural abundance of 13C and 15N in C3 and C4 vegetation of southern Africa: patterns and implications. Global Change Biology 10(3): 350-358.

Talbot MR and Johannessen T (1992) A high resolution palaeoclimatic record for the last 27,500 years in tropical West Africa from the carbon and nitrogen isotopic composition of lacustrine organic matter. Earth and Planetary Science Letters 110(1): 23-37.

Thiéblemont D (2013) Evidence for an aeolian origin of the Holocene lateritic surface cover of Gabon (Central Africa). Quaternary International 296: 176-197.

Thiéblemont D, Flehoc C, Ebang-Obiang M, Rigollet C, Prian J-P and Prognon F (2013) Geochronological arguments for a close relationship between surficial formation profiles and environmental crisis (c. 3000-2000 BP) in Gabon (Central Africa). Comptes Rendus Geoscience 345(7-8): 272-283.

Thiéblemont D, Guerrot C, Négrel Ph, Braucher R, Bourlès DL and Thiéblemont R (2014) Nd-isotope evidence for the distal provenance of the historical (c. $<3000 \mathrm{BP}$ ) lateritic surface cover underlying the Equatorial forest in Gabon (Western Africa). Aeolian Research 15: 177-192.

Weltje GJ and Tjallingii R (2008) Calibration of XRF core scanners for quantitative geochemical logging of sediment cores: Theory and application. Earth and Planetary Science Letters 274(3): 423-438.

White F (1983) The vegetation of Africa. Natural Resources Research, UNESCO 20: 356.

White L and Abernethy K (1997) A Guide to the Vegetation of the Lopé Reserve. Wildlife Conservation Society, 224p. New York.

White LJT (1992) Vegetation history and logging disturbance: Effects on rain forest mammals in the Lope Reserve, Gabon (with special emphasis on elephants and apes). Scotland, University of Edinburgh.

Yang S and Gruber N (2016) The anthropogenic perturbation of the marine nitrogen cycle by atmospheric deposition: Nitrogen cycle feedbacks and the 15N Haber-Bosch effect. Global Biogeochemical Cycles 30(10): 1418-1440. 